\title{
Ver: analogismo e naturalismo em uma cena da Anunciação (c. 1470)
}

Luiz César de Sád ${ }^{*}$

${ }^{1}$ Universidade de Brasília, Brasília/DF - Brasil

\section{RESUMO}

Propõe-se neste texto um desenho teórico para estudo de modos de visualização da pintura na primeira época moderna. A análise da Anunciação, retábulo atribuído a Francesco del Cossa (c. 1470), com o auxílio de uma ontologia das imagens, acarretará três hipóteses que revisam interpretaçóes correntes. Primeira, o retábulo introduzia uma metarrelação entre palavras e coisas tida por efeito direto da Causa Primeira indiretamente testemunhado sob doutrinas teológicas de causalidade. Segunda, os comitentes do retábulo, franciscanos da Osservanza de Bolonha, consumiram a imagem em meio a uma espiritualidade pública nutrida por cultos marianos que encenavam vínculos místicos entre o microcosmo e o macrocosmo. Terceira, os códigos naturalistas da obra, calcados no ponto de vista imperial, na perspectiva e na disposição racional da cena alinhavam-se a um sistema de inferências analogista, de que resultou um realismo híbrido.

Palavras-chave: ontologia das imagens; Anunciação; Francesco del Cossa.

\section{Things (un)seen: analogism and naturalism in an Annunciation scene (c. 1470)}

\section{ABSTRACT}

This article proposes a theoretical perspective for studying the viewing methods of early modern paintings. Analysis of the Annunciation, an altarpiece attributed to Francesco del Cossa (c. 1470), along with an ontology of images, will lead to three hypotheses that reassess current interpretations. First, the altarpiece introduced a metarelation between words and things that had as a direct effect the First Cause indirectly witnessed under theological doctrines of 
causality. Second, its patrons, Franciscans of the Osservanza in Bologna, consumed the image amid a public spirituality nourished by Marian cults that enacted mystical links between the microcosm and the macrocosm. Third, the work's naturalistic codes, based on an imperial viewpoint and in the perspective and the rational disposition of the scene, were aligned with a system of analogist inferences, which resulted in a hybrid realism.

Keywords: ontology of images; Annunciation; Francesco del Cossa.

\section{Ver: analogismo y naturalismo en una escena de la Anunciación (c. 1470)}

\section{RESUMEN}

En este texto se propone un diseño teórico para el estudio de los modos de visualización de la pintura en la primera época moderna. El análisis de la Anunciación, retablo atribuido a Francesco del Cossa (c. 1470), con la ayuda de una ontología de las imágenes, traerá tres hipótesis que revisan interpretaciones actuales. Primera, el retablo introducía una metarrelación entre palabras y cosas tenida por efecto directo de la Causa Primera indirectamente atestiguada sobre las doctrinas teológicas de la causalidad. Segunda, los clientes del retablo, Franciscanos de Osservanza de Bolońa, consumieron la imagen en medio a una espiritualidad pública nutrida por los cultos marianos que escenificaban vínculos místicos entre el microcosmo y el macrocosmo. Tercera, los códigos naturalistas de la obra, calcados en el punto de vista imperial, en la perspectiva y en la disposición racional de la cena se alineaban a un sistema de inferencias analogista, del que resultó un realismo híbrido.

Palabras clave: ontología de las imágenes; Anunciación; Francesco del Cossa.

O ponto de partida deste texto é a identificação do realismo como marca inconcussa de representaçóes pictóricas quatrocentistas. Autonomizado no bojo de um Renascimento estilístico e cultural que boa parte da crítica dos séculos XIX e XX comemorou, ele se explicita a partir de dois pressupostos: de um lado, o nascimento do indivíduo, psicologicamente subjetivado $^{1}$ na arte do retrato; de outro, a emergência de uma oposição entre essa consciência interior e um mundo natural objetivo que se destaca nitidamente dela. ${ }^{2}$ Muito já foi dito sobre

\footnotetext{
${ }^{1}$ Embora a arqueologia do sujeito de Alain de Libera permita delimitar a existência de categorias de sujeito e o quiasma de sua agência - em materiais "medievais" e "modernos", estas decerto não eram "psicológicas" (LIBERA, 2013, p. 411).

${ }^{2}$ Um momento forte dessa convergência encontra-se nas reflexôes de Jacob Burckhardt, ao fazer de Petrarca (e, a seguir, dos pintores do Norte) um dos primeiros a contemplar, do alto do monte Ventoux, o mundo natural, calcado no "reflexo da realidade" que o "conteúdo poético autônomo" do humanista (e pintores) é
} 
o caráter evolutivo desses saberes e a resiliência de seus postulados (KOSSOVITCH, 1994), mas resta elucidar os fundamentos de sua operação, que decerto não decorre de imperícia dos que a forjaram, nem se extenua nas ambiçóes de um projeto intelectual vencido.

Gostaríamos de explorar a hipótese de que o caráter mimético da representação de uma primeira época moderna configurava-se sob princípios de realidade incompatíveis com essa narrativa. A crítica exige a revisáo dos predicados ontológicos que ainda autorizam a percepçáo de que a pintura dita renascentista aciona categorias cognitivas imediatamente apreensíveis, despindo-lhes de seu "verniz de falsa familiaridade" (BAXANDALL, 2006, p. 169). Uma investigação amparada em ferramentas heurísticas permitirá sugerir, primeiro, que os procedimentos figurativos naturalistas então vigentes são irredutíveis ao nosso horizonte realista; segundo, que as técnicas pictóricas quatrocentistas e os modos de vê-las resultavam de um sistema de inferências analogista. As evidências oferecidas aos leitores foram extraídas do estudo das condiçóes ontológicas de visualização de um objeto que denota esse hibridismo, o retábulo da Anunciação (c. 1470), de Francesco del Cossa. ${ }^{3}$

A tela tem sido alvo de debates entre críticos e historiadores da arte, em geral confinados a dois desafios interpretativos com que a presente análise pode contribuir. De um lado, a impossibilidade de nos apoiarmos exclusivamente em informaçóes documentais, dadas as lacunas de arquivo - para além do desinteresse absoluto em aderir a qualquer fetiche da evidência arquivista - que por vezes inibem o acesso às circunstâncias de contratação, de execução e consumo das obras. De outro, o excesso de confiança atribuído à iconologia, levando a supor nelas símbolos a serem decifrados sob uma sintaxe claramente discernível na unidade de um sentido, o que nem sempre é o caso. Ambas presumem um nível de especificidade raramente viável, endossando cadeias especulativas cuja aparente precisão suscita incertezas (BLACK, 1986). É imprescindível manter equidistância dessas abordagens, recusando os extremos da pura legibilidade e da absoluta expressividade simbólica das imagens (BASCHET, 2008, p. 191-192).

A exposição está dividida em três tempos. O primeiro se consagra à descrição das coordenadas que fundamentam uma ontologia das imagens. $\mathrm{O}$ segundo à apreciação do retábulo de Cossa na ordem institucional e teológica que sua contemplação verossimilmente acionava. $\mathrm{O}$ terceiro à conclusão de que um hibridismo ontológico explica por que os critérios realistas do primeiro naturalismo figurativo não devem ser tomados como proêmio necessário do modo de identificação naturalista agora vigente.

livremente capaz de apreender (BURCKHARDT, 2003, p. 221-222). Longe de ser apanágio da historiografia oitocentista, a perspectiva permanece em funcionamento no exame dos objetos artísticos; pode-se detectá-la, por exemplo, na reiterada adjetivação psicopatológica de pintores "renascentistas" - "neuróticos", "febris", "atormentados" - (MANCA, 2001), caso de Francesco del Cossa, objeto deste estudo.

${ }^{3}$ A atribuição remonta ao século XIX, quando Morelli a considerou realizada pela mesma máo que executou a parede oriental do Salone dei mesi do Palácio Schifanoia. Nesse caso, há registro autógrafo de Cossa (HARCK, 1886, p. 48). 


\section{Ontologias da figuração}

O programa lançado por Philippe Descola com a publicação de Par-delà nature et culture tem sido acolhido por estudiosos da antiguidade e do medievo ocidentais por encontrarem nele instrumentos de reposição da alteridade irredutíveis a categorias naturalizadas pelas ciências sociais para descrever outras culturas como diferentes versóes de uma mesma disposição transcendental subsumida a uma concepção objetiva da Natureza (PIRON, 2019, p. 837).

A atualização desses princípios constitutivos se concretiza quando nos detemos na origem das diferentes arquiteturas da experiência humana, ou seja, quando lhe devolvemos seu papel nos processos de composição do mundo: entenda-se com isso as formas adotadas por grupos humanos de qualificar, por meio de filtros ontológicos, a miríade de seres, propriedades e fenômenos que se prestam a sua observação (DESCOLA, 2014, p. 273). As inferências podem ser estruturadas por modos de identificação, isto é, esquemas cognitivos adquiridos ao longo da socialização que orientam, de modo intuitivo, formas de interação, interpretação e ação em um dado ambiente (DESCOLA, 2005).

Deles não emerge uma visão de mundo, mas um mundo em si mesmo, regido por mecanismos antepredicativos postos à prova de outras configuraçôes ontológicas (DESCOLA, 2014, p. 278). Todas são contingentes, e podem sofrer mutaçóes no encontro de indivíduos ou coletivos socializados nos moldes de diferentes esquemas (LLOYD, 2007, p. 149), mas permanecem suficientemente estáveis para que se descrevam as inferências básicas sobre os seres capazes de agência, as qualidades do mundo e as formas de seu relacionamento (DESCOLA, 2018, p. 129). Do ponto de vista desta análise, o esforço de "higiene conceitual" assim formulado deve se unir à investigação da ordem discursiva colhida do vocabulário dos materiais a examinar, pois ele expressa, às vezes detalhadamente, os parâmetros morfológicos da experiência que os modos de identificação estimam em modalidade teórica.

Os modos de identificação também recobrem a experiência figurativa. Ela consiste em usos icônicos e indiciários de imagens em situação (DESCOLA, 2009, p. 521). Icônicos porque as imagens se reportam a identidades que lhes são exteriores, miméticas ou prototípicas. Indiciários porque exprimem sentidos por meio de signos compreensíveis no âmbito da comunidade em que foram forjados. Descola sugere que certas imagens contêm paradigmas de interioridade e de fisicalidade expressivos dos mecanismos de percepção de continuidades e descontinuidades no ambiente. Se o procedimento figurativo é universal, pode ser empiricamente declinado pelas quatro fórmulas ontológicas gerais concebidas por ele, a saber: o animismo, caracterizado pelo reconhecimento de que os seres compartilham o atributo da interioridade, diferenciando-se pela fisicalidade; o naturalismo, regido por posição inversa, isto é, humanos e não-humanos são tidos por semelhantes sob o ponto de vista da fisicalidade, ao passo que apenas aqueles dispóem de interioridade; o totemismo, em que certos humanos 
e não-humanos se agrupam sob classes físico-morais ditadas por protótipos; o analogismo, regime em que todos os elementos do mundo sáo considerados dessemelhantes, de modo que qualquer inteligibilidade depende de redes de correspondência desempenhando o papel de tornar suas relaçôes coerentes. Deve-se tomar essas fórmulas como dispositivos heurísticos capazes de registrar formas contingentes de distribuição de entidades e fenômenos (DESCOLA, 2005, p. 322), e não como estruturas monolíticas que periodizam, na forma de eras ou épocas históricas, classificaçôes totais. Isso é particularmente nítido nas declinaçôes ontológicas que nos interessam, o naturalismo e o analogismo, pois estão imbricadas no ambiente de confecção do retábulo de Cossa.

A ascensão do naturalismo na Europa moderna se deu de forma descontínua. Do ponto de vista normativo, pode-se detectá-lo no conjunto de textos, hoje reconhecidos como "científico-filosóficos", que afirmaram, ao longo dos séculos XVII e XVIII, a existência de uma consciência autorreflexiva, autorizada pelo cogito cartesiano e pela emergência romântica da psicologia autoral, e o espaço e o tempo como estruturas desinteressadas, aplicáveis indistintamente a todos os seres. Todavia, o naturalismo icônico precede essa normatividade em ao menos dois séculos, remontando aos experimentos técnicos da pintura de Borgonha e Flandres.

Os traços de naturalismo da pintura do Norte derivam de dois dispositivos (DESCOLA, 2010, p. 801): a fabricação do realismo - perceptível tanto na técnica do retrato quanto na presença ostensiva do ponto de vista do pintor - e o privilégio das continuidades físicas, com a autonomização da paisagem. Se as composições paisagísticas são minuciosamente elaboradas no segundo plano de cenas sacras e citadinas durante o século XV (Figura 1), ${ }^{4}$ na centúria seguinte pintores como Patinir (Figura 2) ampliam sua independência, invertendo as escalas: as marcas da presença humana diminuem e em alguns casos desaparecem em meio às vastas porçóes de território intocadas por ela (DESCOLA, 2010).

\footnotetext{
4 "Divorciados dos ícones do primeiro plano, as árvores, as plantas, os animais, os edifícios se constituem assim em uma totalidade homogênea, às vezes em detrimento de um vínculo verossímil com a cena sagrada" (DESCOLA, 2009, p. 534).
} 
Figura 1: Jan van Eyck. A Virgem do chanceler. Rolin, 1435. Óleo sobre madeira, 66 x 62 cm., Musée du Louvre.

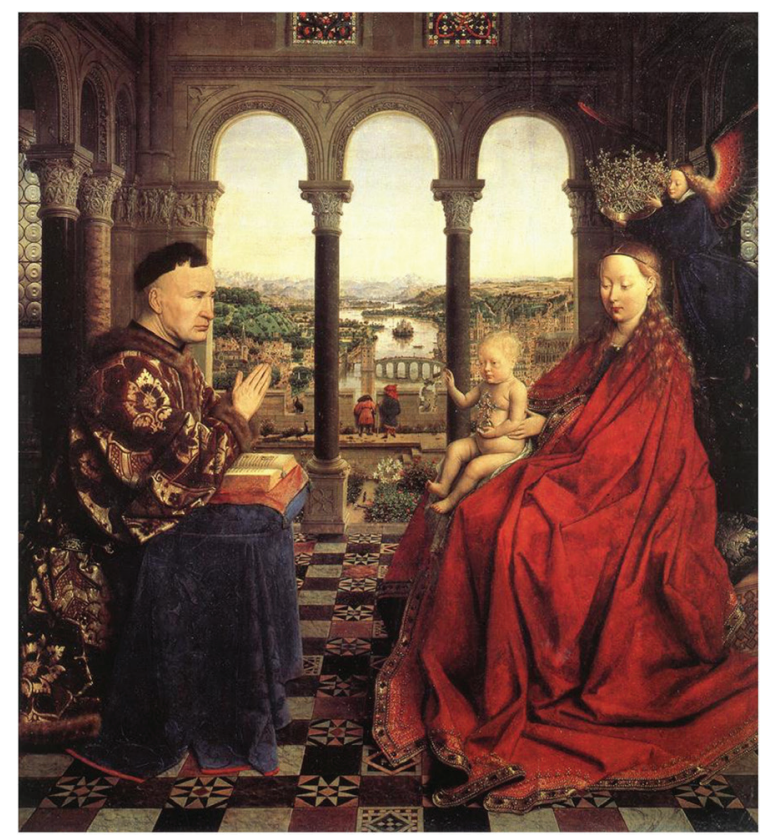

Foto: Wikimedia Commons.

Figura 2: Joachim Patinir. Paisagem com São Jerônimo, c. 1517. Óleo sobre painel, 74 x 91 cm., Museo del Prado.

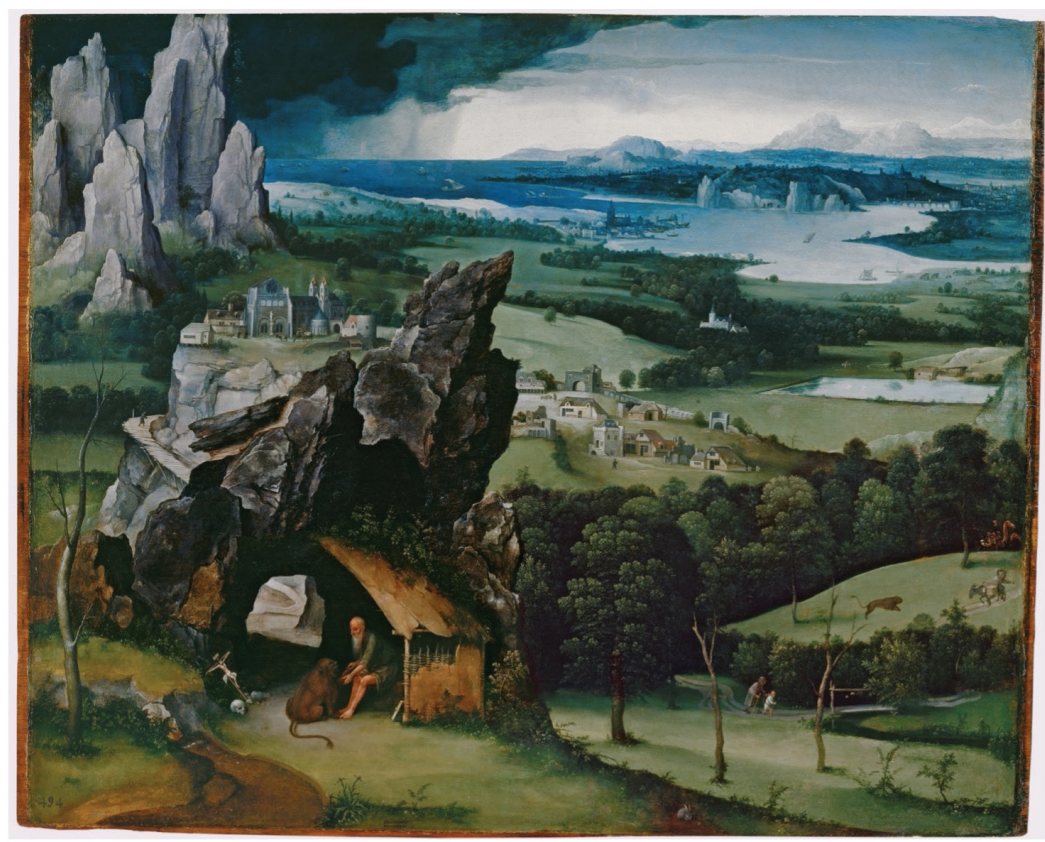

Foto: Wikimedia Commons. 
Tudo isso acarretou uma prática artística voltada para a observação precisa de ambientes empíricos - a ponto de o mundo material passar, a partir do século XVII, ao patamar de tema pictórico (ALPERS, 1999) - em estrita afinidade com a emergência de aparatos de objetivação (microscópios, telescópios etc.). Eles não eram "científicos" na acepção corrente, pois detectavam o mundo natural através de filtros metafísicos (postulando Deus como criador de uma ordem natural autossuficiente) (SCHMUTZ, 2001, p. 219), mas sinalizam em definitivo para a percepção de um universo regido por estruturas "uniformes, universais e invioláveis" (DASTON, 2019, p. 25). As preceptivas holandesas registram o empenho mimético característico desse momento naturalista com a expressão naer het leven ${ }^{5}$, empregada no sentido específico de obra realizada com base em modelos empíricos ou para esse efeito (SWAN, 1995, p. 355). Supostamente eximidas da ingerência da fantasia criadora, as representaçôes ad vivum teriam, a longo prazo, levado o dispositivo retórico-poético da autópsia à exaustão, selando o valor de "fato visual" das imagens (SWAN, 1995, p. 357), possibilidade que se prepara desde os desenhos de Roelandt Savery (Figura 3).

Figura 3: Roelandt Savery. Homem sentado, c. 1608. Lápis e tinta sobre metal, 15 x 17 cm, Getty Museum.

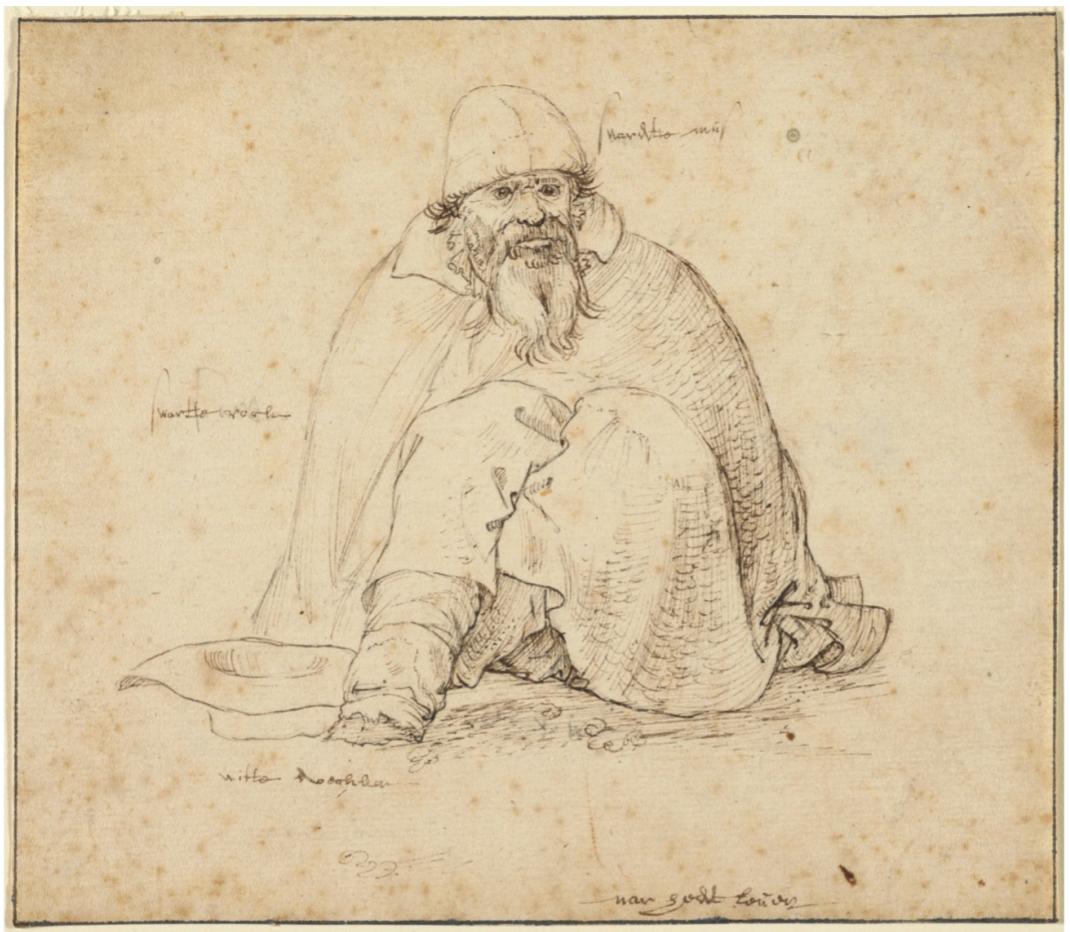

Foto: Wikimedia Commons.

\footnotetext{
${ }^{5}$ Embora a expressão conste dos repertórios públicos daquele universo letrado pelo menos desde Villard d'Honnecourt (GOMBRICH, 2007, p. 67-68), ela passa a ser empregada com valor de fato visual no século XVII (SWAN, 1995, p. 355).
} 
O filáo do naturalismo de onde se origina a correspondência mimética entre representação pictórica e o mundo material está, entretanto, longe de caracterizar univocamente o naturalismo dito renascentista. Descola adverte que mesmo no mundo flamengo não se ignorou, nos gêneros sacros e alegóricos, a simbolização que a história da arte veio a sistematizar segundo critérios iconológicos. $\mathrm{O}$ mesmo pode ser dito da pintura italiana, cuja proximidade do modelo do ut pictura poesis ${ }^{6}$ e de postulados teológicos constitutivos da experiência humana garantia inserção em uma ordem discursiva comprometida com a visualização da pintura segundo signos aquém e além do visível (BAXANDALL, 1991, p. 45). Nada, senão a epistemologia evolutiva de uma história dos estilos, permitiria deduzir a metamorfose das representaçôes ad vivum em imagens científicas que traduzem um mundo puramente objetivo.

O mesmo pode ser dito da interioridade. Se de fato verificamos na pintura do século XV a ascensão de representaçôes de indivíduos empíricos, suas paixões não são emanaçôes de sentimentos privados na iminência de se revelar, mas fisionomias colhidas em repertórios emocionais públicos (BAXANDALL, 1991, p. 61). Analogamente, a individualização não revoga o horizonte das posiçóes estamentais dos indivíduos, socialmente constituídas segundo os graus hierárquicos da dignidade de seus ofícios perante o corpo místico-político da comunidade que habitam.

$\mathrm{Na}$ contramão de qualquer dicotomia opondo um paradigma de representação "medieval" à emergência da "modernidade artística" no século XV, os muitos tempos em que o modo de identificação naturalista prosperou revelam várias formas de interioridade e de realismo, que tendemos a recortar em benefício do que o modo de identificação naturalista atualmente vigente pressupõe. Entre os dispositivos pictóricos pertinentes a esta análise, a situação é concretamente híbrida, uma vez que o naturalismo figurativo se manteve em simbiose com o modo de identificação até então acessado de forma mais recorrente (DESCOLA, 2011, p. 697), o analogismo.

As diferenças de interioridade da ontologia naturalista reduplicam-se no analogismo como descontinuidade geral típica de um mundo caracterizado por uma profusão de singularidades tornadas inteligíveis graças a dispositivos unificadores que estabelecem conveniências entre os seres, discursos e qualidades. Por isso, a figuração analogista, mesmo quando realista, não pretendia dar a ver cenas objetivas, mas uma "trama de afinidades" interligando entidades e fenômenos (DESCOLA, 2010, p. 810).

\footnotetext{
${ }^{6}$ A comparação entre poetas e pintores ocorre em Dante e Petrarca, entre outros, a partir da aequiparatio (KANTOROWICZ, 1984, p. 51-53). Participando de um mesmo costume letrado, as particularidades imanentes das técnicas podiam se intercambiar no comércio de costumes retórico-poéticos. Não se depreenda, com isso, paralelos absolutos, como se fosse exigido, "para cada poeta designado, um pintor" (KOSSOVITCH, 1994, p. 61).
} 
No século XV, o princípio organizador é descrito como Causa Primeira que todos os elementos do mundo refletem singular e imperfeitamente. Este é um dado essencial, pois explicita um fundamento repetidas vezes esquecido: ao invés de denotar uma relação imperfeita entre dois elementos diferentes, a analogia quatrocentista foi balizada por relaçóes perfeitas entre eles (MOCHIRI, 2016, p. 115). Ela se ampara em conceitos de causalidade que nossas categorias também desconhecem: a dependência em relação à Causa Primeira não se dá exclusivamente na origem da criação, mas na substância que vincula a totalidade do mundo (FOUCAULT, 2016, p. 52). Embora não dependam exclusivamente, uma vez criadas, da ação divina (aspecto indispensável ao exercício do livre-arbítrio), somente existem exatamente do modo como existem graças à sua participação no ser. A partir dessa "criação continuada" erige-se, ademais, a modalidade hierárquica dos relacionamentos entre os seres e o ambiente, cujo teatro cósmico ilustra a singularidade e a variedade da obra divina (MOCHIRI, 2016, p. 125).

A metafísica assim consumida aproximava microcosmo e macrocosmo. Nas hierarquias e funçôes conferidas pelo grau de proximidade dos seres em relação ao criador fundava-se o bem comum pacificamente depositado no corpo teológico-político, regulando a experiência do cotidiano na institucionalidade de uma ordo iuris (GROSSI, 2014, p. 16). ${ }^{7}$ A dimensão prática das conveniências cósmicas (DESCOLA, 2005, p. 302) se expressa, ainda, nas fisicalidades, como notamos graças aos compêndios médicos que circularam no século XV, cujas prescriçôes ativavam uma ciência das correspondências.

As imagens inseridas nos tratados revelam as correspondências entre microcosmo e macrocosmo mediante figuraçôes do homo signorum (Figura 4). Elas não registram um discurso médico especializado e objetivo, mas a decifração imagética dos elementos constitutivos do real plasmados nos costumes técnicos. Semelhante relação ocorre na figura do homem zodiacal inscrito no Livro das propriedades de Bartholomaeus Anglicus (Figura 5), que explicita o impacto dos astros no plano corpóreo - a exemplo da escolha da boa data para a intervenção médica, determinada conforme o signo do paciente. Juntos, o corpo humano, o corpo jurídico e os corpos celestes orquestram, em mise en abîme, a geometria harmônica do universo (BORELLA, 2000, p. 11).

\footnotetext{
${ }^{7}$ Vínculos entre a ideia de imitação da natureza nos dispositivos jurídicos e "artísticos" do período foram convincentemente demonstrados por Kantorowicz (1984, p. 39-41).
} 
Figura 4: Yuhanna Ibn Sarafiyun. Homo signorum. Recueil de traités médicaux Séfarade, séc. XIV, f. 263.

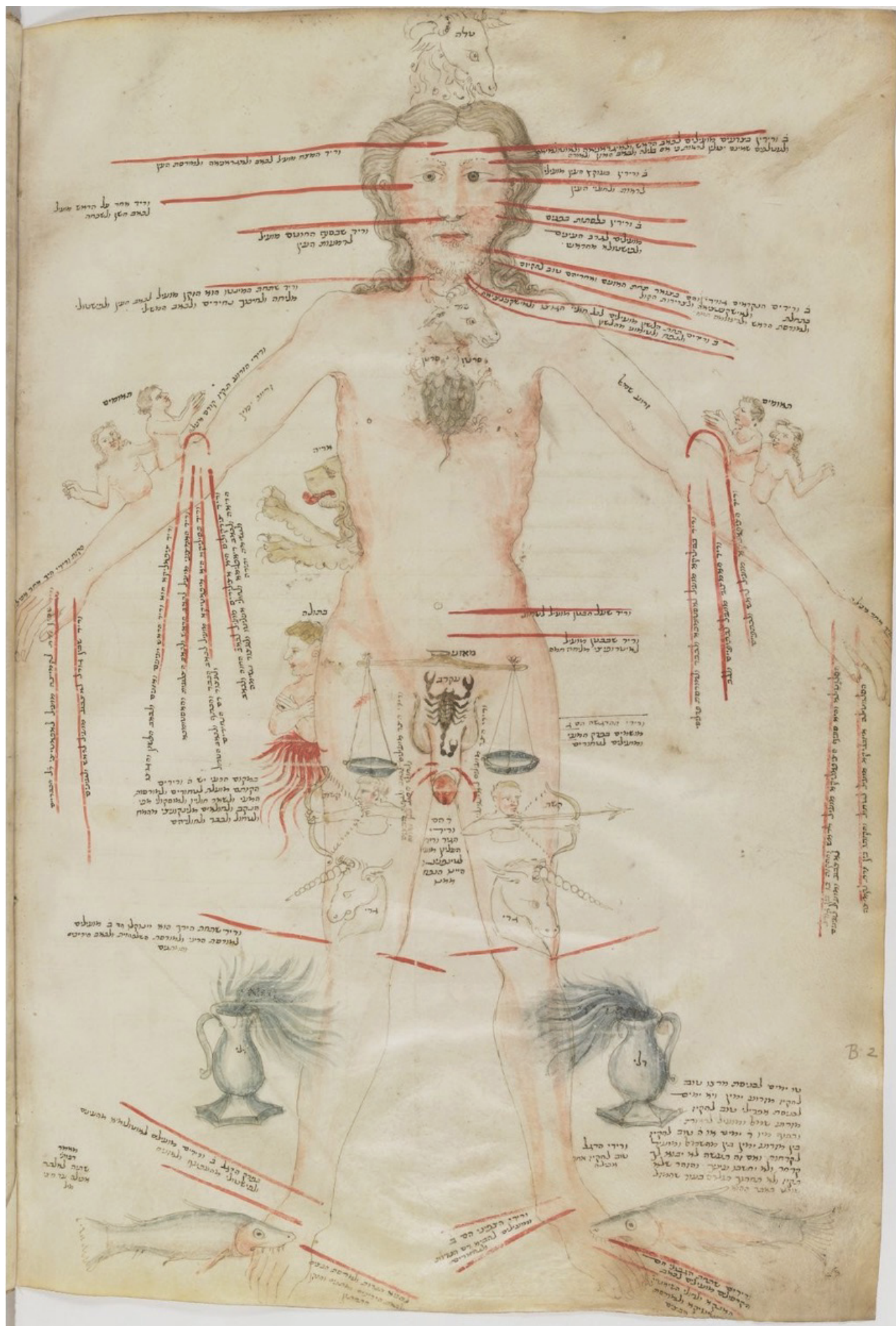

Fonte: Bibliothèque Nationale de France. 
Figura 5: Bartholomeu, o inglês. Homem zodiacal. Livre des Propriétés des Choses, séc. XV, f. 48v.

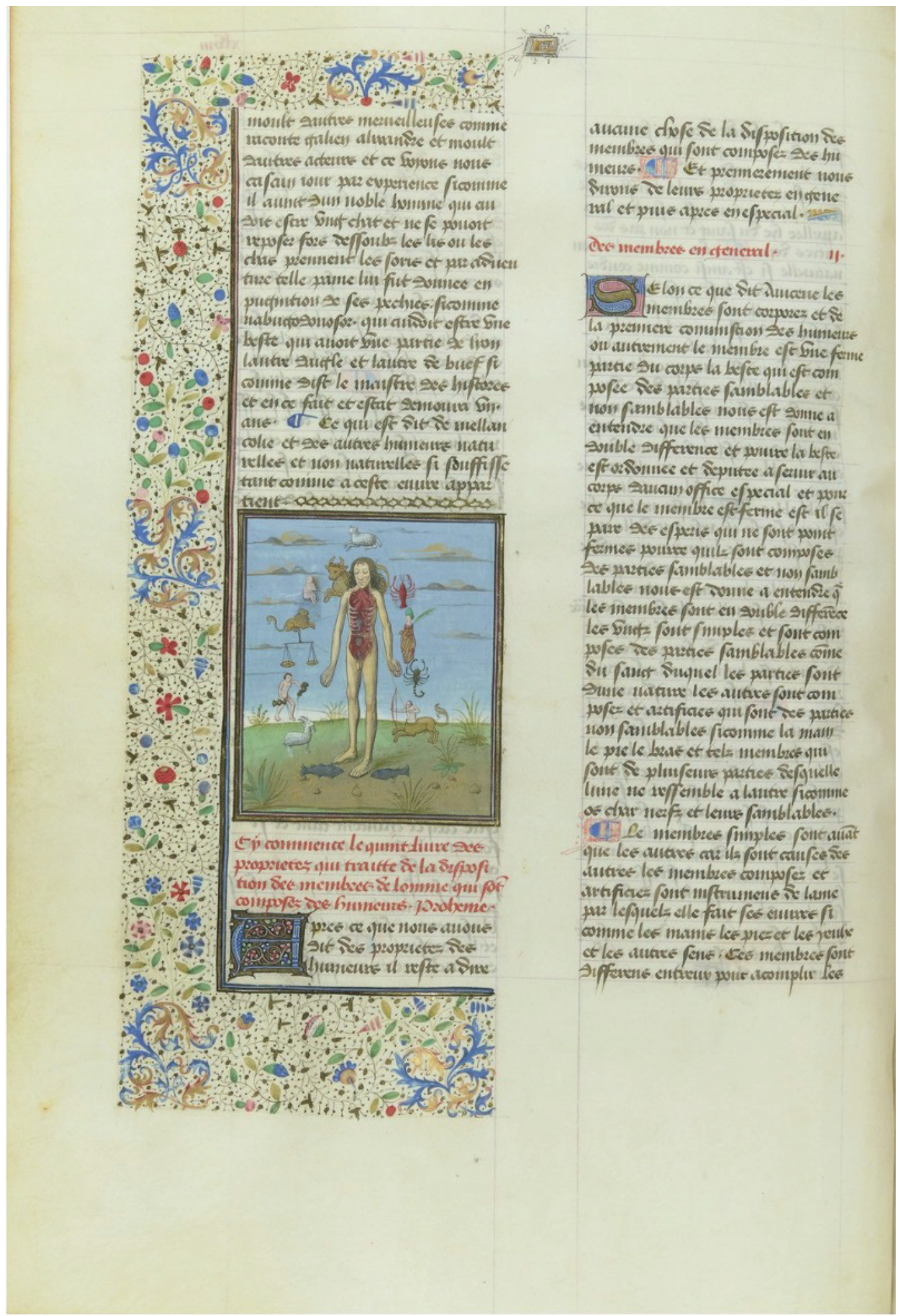

Fonte: Bibliothèque Nationale de France. 
O retábulo da Anunciação foi construído segundo critérios que marcaram, a posteriori, uma ruptura diante da figuração analogista (DESCOLA, 2011, p. 696), mas de modo algum pode ser desassociado dos dispositivos analogistas de identificação de seu tempo. Por isso, devemos situar os modos de identificação sob a luz de seu hibridismo constitutivo, identificável em materiais poético-teológicos consumidos no período, decisivos no aparecimento do "olho do Quattrocento" (BAXANDALL, 1991). ${ }^{8}$ De antemão, insistamos que as relaçóes acima descritas derivavam de um filtro ontológico que enfocava a sistematização das singularidades do mundo através de cadeias de referências. Desconhecendo o continuum biofísico que, no naturalismo contemporâneo, apenas equipara os seres na materialidade de seus corpos, os hierarquizava em um plano físico-espiritual. Essa perspectiva não escapava à pintura; a experiência de conceber e de ver um retábulo impelia à contemplação espiritual do universo material, e, em certos casos, à decifração de seus arcanos.

\section{In speculo et aenigmate}

Verticalmente partida por uma coluna central opondo Maria ao anjo Gabriel, a Anunciação (Figura 6) institui planos sucessivos que, se chamam atençấo pelo efeito de sobrecarga que à primeira vista podem suscitar, não deixam de exibir agudeza técnica ao infundir no retábulo uma profusão de agências mundanas e sagradas distribuídas segundo os decoros de sua coabitação.

A perícia de Cossa é aparente desde o primeiro plano, no feixe diagonal que liga o anjo e a Virgem, esta aparentemente ladeada pelo Novo Testamento, que sobressai em seus aposentos. Do lado de Gabriel, Cossa dá a ver toda uma cena citadina de que participam um cão caminhando; acima dele, um edifício onde uma mulher parece observar o episódio com uma criança nos braços e, mais recuados, indivíduos que adentram os portóes da cidade. Nos céus vemos o Deus altíssimo que envia ao mundo a colomba do Espírito Santo, de onde derrama a luz oblíqua que atravessa as personagens até tocar o chão de mármore percorrido por um caracol posicionado nos limites da tela.

\footnotetext{
${ }^{8}$ Sylvain Piron sugere que, em longo prazo, a separação ontológica decorre da purificação do conceito de natureza, despido dos aspectos sobrenaturais que o constituíam, grosso modo, entre os séculos XIII e XV (PIRON, 2019, p. 838).
} 
Figura 6: Francesco del Cossa. Anunciação, c. 1472. Têmpera sobre madeira, 139 x 113,5 cm., Gemäldegalerie Alte Meister.

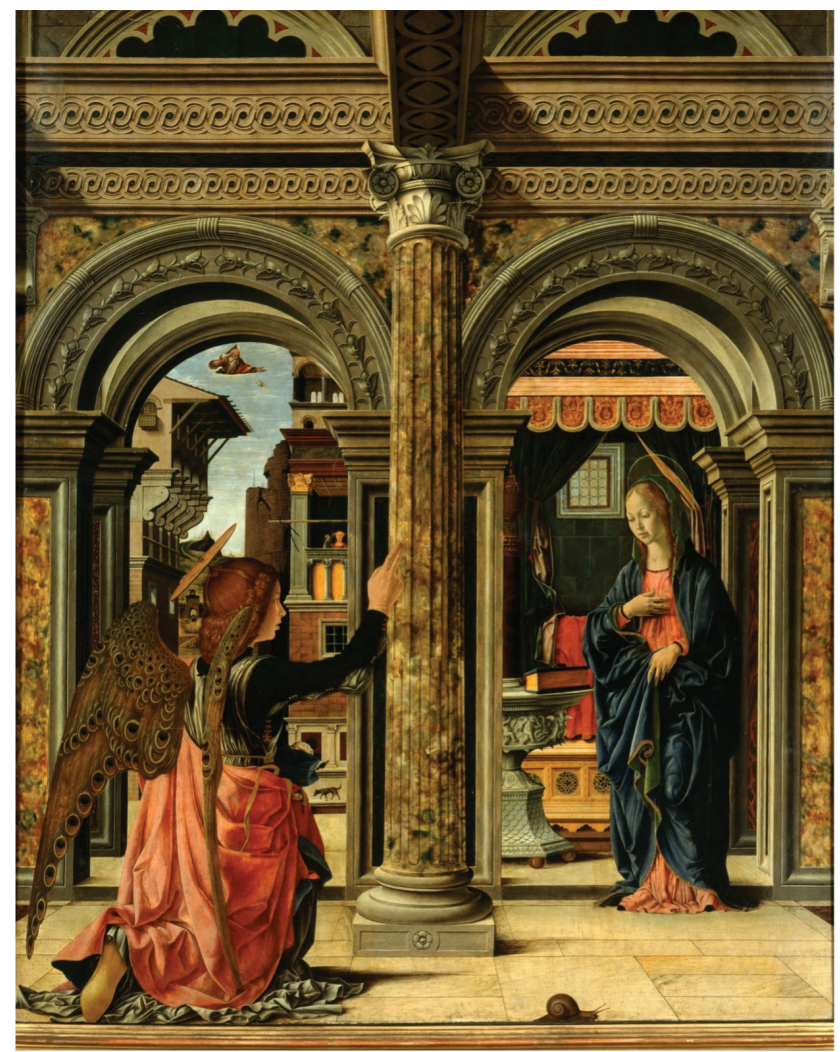

Foto: Wikimedia Commons.

Esses aspectos figurativos devem ser examinados na latitude dos repertórios teológicos disponíveis entre os comitentes, nas experiências públicas de culto mariano então típicas em Bolonha e na comparação dos dispositivos empregados por Cossa com outros exemplares do gênero. Todos remetem, em alguma medida, à fonte testamentária do episódio, o evangelho de Lucas, para onde parece se dirigir a atenção de Maria na cena pintada por Cossa - seria este, aliás, o trecho marcado no livro? (Figura 7) - e, com ela, o olhar dos observadores:

Ao sexto mês, o anjo Gabriel foi enviado por Deus à cidade da Galileia cujo nome era Nazaré, para junto de uma virgem desposada com um homem chamado José da casa de Davi; e o nome da virgem era Maria. E entrando [em casa] em direção a ela, [o anjo] disse: "Salve, favorecida (Maria, plena de graça)! O senhor [está] contigo (e és bendita entre todas as mulheres)!”. Ela perturbou-se com essas palavras e interrogava-se que forma de saudação seria aquela. E disse-lhe o anjo: "Não temas, Maria, pois achaste graça junto de Deus. E eis que conceberás no ventre e parturirás um filho e pôr-lhe-ás o nome de Jesus. Ele será grande e será chamado Filho do Altíssimo e o Senhor dar-lhe-á o trono de Davi, seu pai, e reinará sobre a casa de Jacó até [o 
fim de] os séculos e do reino dele não haverá fim”. Disse Maria ao anjo: “Como será isso, uma vez que não conheço homem?”. E o anjo, respondendo-lhe, disse-lhe: "Um espírito santo virá sobre ti e o poder do Altíssimo te sombreará. Por isso, o concebido é santo e chamar-se-á filho de Deus. E eis que Isabel, tua parente, também ela concebeu um filho na sua idade! E este mês [já] é o sexto [da gravidez] dela, a chamada estéril. Porque não ficará impossibilitada da parte de Deus toda a palavra". Maria disse: "Eis a escrava do Senhor. Aconteça-me segundo a tua palavra”. E retirou-se de junto dela o anjo (LUCAS, 1: 26-38). ${ }^{9}$

Figura 7: Francesco del Cossa. Anunciação (detalhe).

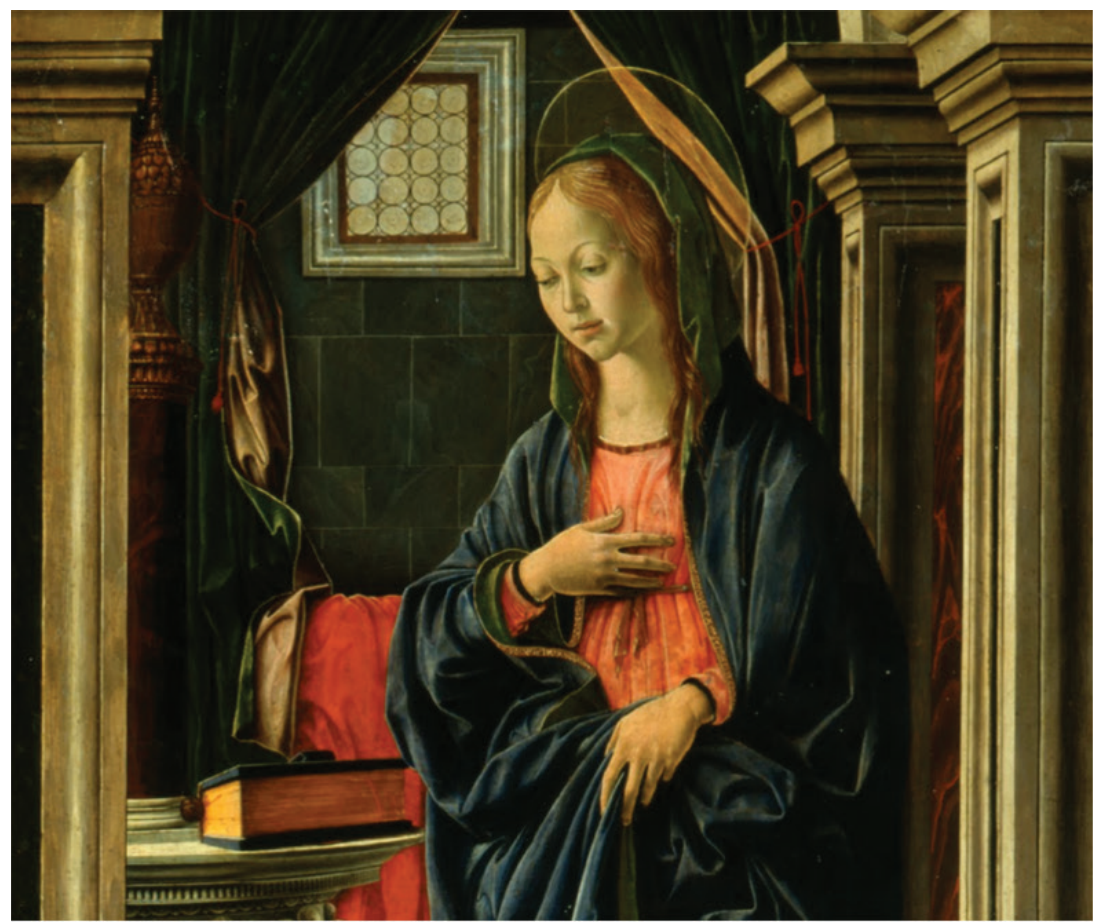

\footnotetext{
${ }^{9}$ As bíblias em vulgar do período registram texto em geral condizente com a tradução que empregamos, de Frederico Lourenço, complementada pelos trechos entre parêntesis, de nossa responsabilidade: "Onde nel sexto mese mando dio langelo gabriele nela provincia de galilea nela citta de nazareth a una vergie desponsata a uno homo: el cui nome era ioseph de la casa de david el nome dela vergine era maria: \& intrando langelo a lei disse: dio te salvi maria piena di gratia. Dio e teco: $\&$ sei benedetta sopra tutte le femine. Et quella vedendo questo da langelo fu turbata per el parlare suo $\&$ pensava quella salutatione fusse questa. Et langelo disse a lei. Non temere maria: im perho che hai trovato gratia apresso dio: ecco che conceperai nel ventre tuo: \& parturirai un figliolo \& chiamarai el nome suo iesu. Questo sara grande \& sara chiamato figliolo del altissimo: \& dara a lui el signor dio la sedia del suo patre david: $\&$ regnara ne la casa de iacob in eterno: \& el suo regno non hara fine. Et maria disse a langelo: come fara questo inpho che non cognosco homo: langelo rispose $\&$ disse a lei Lo spirito sancto sopravignera in te: $\&$ la virtu del altissimo obrunbara te $\&$ colui cb nascera di te fara sancto: $\&$ sara chiamato figliolo de dio. Et ecco elisabeth cognata tua la quella ha conceputo el figliolo ne la vechieza sua: \& questo e el sexto mese di quella: che è chiamata sterile: im per ho che apresso dio non fara impossibile ogni parola. Alhora disse maria. Ecco lancilla del signor: sia facto a me secondo la parola tua: e langelo partisse da quella" (LUCAS, 1490, fl. 358r).
} 
Os estudos de Baxandall (1991, p. 55-56) apontam convincentemente a sinergia entre a passagem e os critérios de seu uso na pintura, transcritos em sermóes do período. Esse cruzamento de referências é chancelado pelo caráter protocolar da confecção de retábulos; a dignidade da função que desempenhavam era mantida ao custo de um rígido controle, de que restam vestígios. ${ }^{10}$ Com eles, pode-se assumir um preceito, a saber, a apresentação dos laços entre o mundo sublunar a intervenção misteriosa do criador, e quatro dispositivos para torná-lo visível: a representação icônica do Espírito Santo e a presença material de Gabriel entre os mortais; a dignidade angélica, revelada no volume, na disposição e no gesto do anjo (ARASSE, 2019), a que se une a pureza que não pertence a este mundo simbolizada por seu sapato, limpíssimo por jamais haver tocado solo humano (SIMONS, 2015, p. 318); a atribuição de numa ocasiáo específica ao evento, sexta-feira, 25 de março, aludindo à vitória da luz sobre as trevas comemorada a cada primavera, e o local preciso onde ocorre, Nazaré - assimilado, no presente da contemplação, a Bolonha.

Esperava-se, ainda, que o retábulo cumprisse protocolos específicos no desenlace da narrativa. Na saudação, Gabriel deveria reverenciar Maria, e esta não expressaria tormento espiritual ou afliçấo física no momento da concepçáo, recendendo à beatitude de quem teve a alma inundada pela presença de Cristo. O colóquio angélico deveria acompanhar de perto os momentos fortes do evangelho, cujos efeitos seriam regidos por cinco estados espirituais passíveis de serem atribuídos à Virgem - conturbatio, cogitatio, interrogatio, humiliatio e meritatio. À exceção do estado de meritatio, cuja diegese operava nos eventos sucedidos após a partida de Gabriel, os demais constituem o repertório mínimo ${ }^{11}$ para a visualização da cena. Ei-lo: Maria reage, atônita ("perturbou-se com essas palavras"), ante a irrupção inesperada de Gabriel, sem no entanto abandonar a prudência que recomenda reflexão ("e interrogava-se que forma de saudação seria aquela"), externando, ato contínuo, o valor pétreo da castidade ("Como será isso, uma vez que não conheço homem?”) e a submissão própria de quem aceita mansamente ("aconteça-me segundo a tua palavra") o destino anunciado (BAXANDALL, 1991, p. 58-59).

Não sabemos se Cossa operou explicitamente esse gabarito, embora as esparsas linhas que dois letrados de Bologna, Angelo Michele Salimbeni e Sebastiano Aldrovandi, lhe dedicaram à guisa de etopeia pouco após sua morte insistam no valor de seu engenho integrando a capacidade de pintar à "vida religiosa" que levou (SALIMBENI; ALDROVANDI, 1477, p. 236). Tomemos o louvor com um grão de sal, reconduzindo-o aos critérios do gênero epidítico,

10 “[...] é para ele que os espíritos se erguem no momento mais importante do rito sagrado e, por isso, não pode ter a mesma liberdade de concepçáo que encontramos nos afrescos das paredes de uma capela ou nos desenhos que ornamentam os livros religiosos" (BAXANDALL, 2006, p. 158).

${ }^{11}$ Referimo-nos a um repertório mínimo para enfatizar que a solução testamentária não esgota as possibilidades de visualização do retábulo, uma vez que ela também remete a uma história visual que convida à comparação com outras imagens da Anunciação (BAXANDALL, 2003, p. 125), o que faremos adiante. Por outro lado, o texto fixa um horizonte de apoio à administração, como dizia Panofsky, da inevitável "violência do intérprete" (GHELARDI, 2008, p. 100). 
articulado à epístola ${ }^{12}$ que o contém; isto implica afirmar que os comentários foram forjados como panegírico, colhendo da vida extinta exemplos morais e autoridade técnica para proveito póstero (PÉCORA, 2002, p. 49). Tendo em vista a necessidade de aludir a qualidades de forma breve e potente, os letrados escolheram sublinhar sua devoção humilde, "inimigo mortal" que era "de pompas e riqueza", de que resultava um afeto inabalável por Cristo. Esta era igualmente estipulada pelo tratado de Alberti, que considerava essencial, no ofício do pintor, a busca de lode, gratia e benivolenza, elementos mais importantes do que a riqueza (ALBERTI, 1547, p. 37). Se nada dizem sobre suas intençóes ou personalidade ${ }^{13}$, as qualidades se inscrevem no ethos de Cossa, e provavelmente desempenharam papel relevante na conquista de uma série de contratos (LIPPINCOTT, 2003, p. 3) executados em conventos e igrejas de Bologna, entre eles o da Osservanza, de onde partiu a encomenda do retábulo (SIMONS, 2015).

A devoção sugerida nessa "pintura da alma” alinhava-se às práticas religiosas da cidade, notadamente espiritualizada na sequência de uma série de reformas dirigidas pelo bispo, e depois cardeal, Nicolò Albergati. Entre 1417 e 1443, as confrarias dominicanas e franciscanas foram estimuladas a organizar ritos públicos de culto mariano, que culminaram em um cotidiano de procissóes, em especial a dois locais: o santuário da Virgem em Guardia e a imagem de Maria nas colinas da Osservanza, em Madonna del Monte, movimento acentuado em contextos de crise; as inundaçóes de 1433 motivaram Albergati a delegar aos irmáos de S. Maria della Morte que fizessem procissão com a imagem da Madonna dell'Impruneta de Florença, associada a milagres relativos a secas e enchentes. Com o fim da ação, franciscanos celebraram missa em nome do retorno da imagem a seu lugar de origem, em Guardia. Albergati determinou, em seguida, procissóes anuais, e consolidou-se a ideia de que a imagem teria sido concedida por São Lucas, fonte dos efeitos miraculosos por ela desencadeados (TERPSTRA, 1995, p. 24-25).

Nas atividades se inseria, ainda, o esforço pedagógico das sacre rappresentazioni - apresentaçóes públicas dos ensinamentos a partir de textos versificados, de que temos notícias graças a códices como o organizado por Tommaso Leoni. Ele compila apresentaçôes da Anunciação, a exemplo da Festa de lannunciata Vergene Maria, além de outros episódios em que sua intervenção teria sido decisiva ${ }^{14}$ (TERPSTRA, 1995, p. 20-22). Realizadas pelos irmãos leigos da Compagnia di S. Girolamo, consistiam em narrações dramáticas de episódios bíblicos nas ruas e igrejas com o auxílio de catecismos. Uma delas, realizada en-

\footnotetext{
${ }^{12} \mathrm{O}$ códice que contém folhas epistolares sob o título Philomatia é, ademais, a principal evidência da bios de Cossa (LIPPINCOTT, 2003).

${ }^{13}$ Para demonstrar como não há valor psicológico-moral nessa associação, basta lembrar que Cossa teria se mudado de Ferrara para Bologna sob o argumento de que o pagamento recebido para participar da concepçáo e confecção do Salone dei Mesi do Palácio Schifanoia era injusto. Em carta a Borso d'Este, exalta seu bom nome e lamenta que seus vencimentos se equiparem aos dos mais baixos aprendizes de Ferrara (COSSA, 1885 , p. 385).

${ }_{14}$ Para o estudo das sacre rappresentazioni, cf. o Ms. Vitt.Em.483, atualmente sob guarda da Biblioteca Nazionale Centrale Vittorio Emanuele II, em Roma.
} 
tre 1465 e 1480, desenvolveu o tema de Santa Maria della Misericordia, realizado no interior da Sacra rappresentazione di Gesù Cristo, San Domenico e San Francesco: o povo é convocado a arrepender-se da soberba, avareza e luxúria que infestavam a cidade antes que Cristo a destruísse com três lanças. Cercado de santos que tentavam impedir a punição, Cristo mostra-se irredutível, e é apenas demovido quando o anjo Gabriel busca o auxílio da Virgem, que, lembrando-lhe os exemplos de São Domingos de Gusmão e de São Francisco, consegue apaziguá-lo ${ }^{15}$.

Os exemplos participam de uma experiência coletiva de devoção mariana elaborada diversamente pelas ordens religiosas de Bolonha. De saída, deve-se marcar a moralização do cotidiano que esses cultos imprimiam ${ }^{16}$ e a ordem mística que supunham (PHILLIPS-COURT, 2007, p. 236); o milagre da Anunciação, calcado em afetos festivos ${ }^{17}$ e contemplativos (BAXANDALL, 1991, p. 72), incutia em suas audiências a presença protetora dos santos e de Maria num spasso spirituale alegorizado, entre outras possibilidades, em imagens da Madonna della Misericordia (Figura 8). A comemoração dos mistérios através desses instrumentos revestia o ato de ver com uma sacralidade apenas compreendida no interior de um sistema de inferências calcado em modos de causalidade que vinculavam o natural e o sobrenatural, a representaçáo também aí assimilada como partícipe da substância divina. Uma tipologia extraída dos dogmas dominicanos e franciscanos indica que, de modo geral, o visível figura o invisível nos termos de uma hermenêutica espiritual que o solo da vida humana antecipa na forma de um estado de plenitude real e autêntico. Ambos se comunicam per influentiam, presumindo, no entendimento tomista, que Deus opera em todo agente (SCHMUTZ, 2001, p. 225).

${ }^{15}$ LEONI, Tommaso. Manoscritto dele Sacre Rappresentazioni ad uso della Compagnia di S. Girolamo di Bologna. Ms. Vitt.Em.483, 1486, f. 134v-141r.

${ }^{16}$ Como ressalta Phillips-Court (2007, p. 247), a cotidianidade da Anunciação permitia a combinação, particularmente cara aos franciscanos, de sublimitas e humilitas.

${ }^{17}$ Nygren (2004) ressalta que as festas também transcorriam em gênero cômico, o que repercutia nas escolhas pictóricas de Lippi, por exemplo, que elegeu o humor como dispositivo de admoestação moral no retábulo Barbadori. 
Figura 8: Piero della Francesca. Madonna della misericordia, c. 1462. Óleo e têmpera sobre painel, 180 x $71 \mathrm{~cm}$, Museo Civico di Sansepolcro.

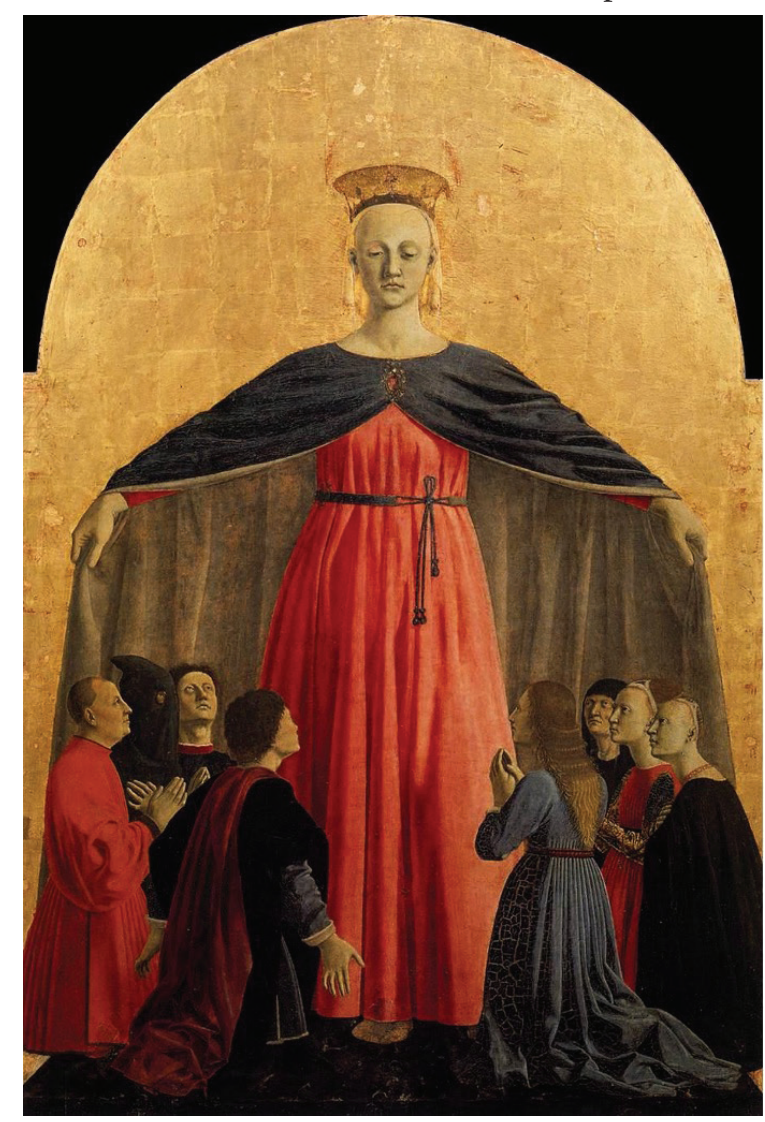

Foto: Wikimedia Commons.

Lidas dessa forma ${ }^{18}$, as sacre rappresentazioni serviam de "pinturas vivas" do mistério, isto é, sedes para profecias (PHILLIPS-COURT, 2007, p. 241), mesma posição ocupada por muitas pinturas da Anunciação. Em termos pictóricos, a interpretação figural (AUERBACH, 1997) é flagrada ostensivamente nas tipologias elaboradas por Fra Angelico e outros pintores de seu círculo. Os episódios bíblicos dos painéis do chamado Armadio degli argenti contêm inscriçóes vetero e neotestamentárias, tornando explícito o que intuímos em outros materiais do gênero. Nesta Anunciação (Figura 9), temos a figura assinalada em uma passagem de Isaías (7:14), Ecce virgo concipiet et pariet filium et vocabit eius Emanuel, "eis que uma virgem conceberá e dará a luz a um filho chamado Emanuel", e seu desdobramento, efetuado no evangelho de Lucas (1:31), Ecce concipies in útero et paries filium et vocabis nomen eius Ihesum, “eis que conceberás no ventre e parturirás um filho e pôr-lhe-ás o nome de Jesus”. Este realiza

\footnotetext{
${ }^{18}$ Também deve ser levado em conta o caráter cômico de algumas dessas rappresentazioni, nas quais a audiência era deleitada com variaçóes em que Maria confunde Gabriel com um jovem intrometido que irrompe em sua casa com histórias absurdas etc. (NYGREN, 2004, p. 183).
} 
o que aquela profetiza; no Antigo Testamento, fala-se de um sinal a ser enviado por Deus, de uma virgem que conceberá, do nascimento exitoso de seu filho. O Novo concretiza o anúncio esperado, certificando a relação analógica posta diante dos olhos de suas audiências: elas não apenas liam a Palavra, mas a apreendiam espiritualmente, entrelaçando, em definitivo, as palavras e as coisas no horizonte da contemplação.

Assim, pode-se supor que as inscriçôes não eram vistas táo-somente como legendas que descrevem a imagem, mas como formas substancializadas dela, o que os pintores da oficina de Fra Angelico denotam compondo o Antigo Testamento em letras e fundo mais escuros, ao passo que o Novo Testamento se apresenta no contraste luminoso que ressalta seu valor consumado (HODNE, 2011, p. 247). Isso significa que as partes constitutivas da cena se vinculavam de modo real, na esfera de um "ordenamento ontológico do um ao Outro" (BORELLA, 2000, p. 84), sem no entanto desconsiderar que "o que as criaturas têm em comum com o Criador não se situa em uma forma, mas se efetua por uma relação" (BORELLA, 2000, p. 85). A pintura proporcionava um realismo analogista que cooptava as audiências, instigadas a ver na profusáo de gestos pictóricos e teatrais formas substancializadas. Estas tornavam-se, no ato de contemplar, coextensôes dessa mesma unidade metafísica, simultaneamente singular e cotidiana, sublime e humilde.

Figura 9: Fra Angelico. Anunciação, c. 1452. Têmpera sobre painel, 123 x 160 cm, Museo Nazionale di San Marco.

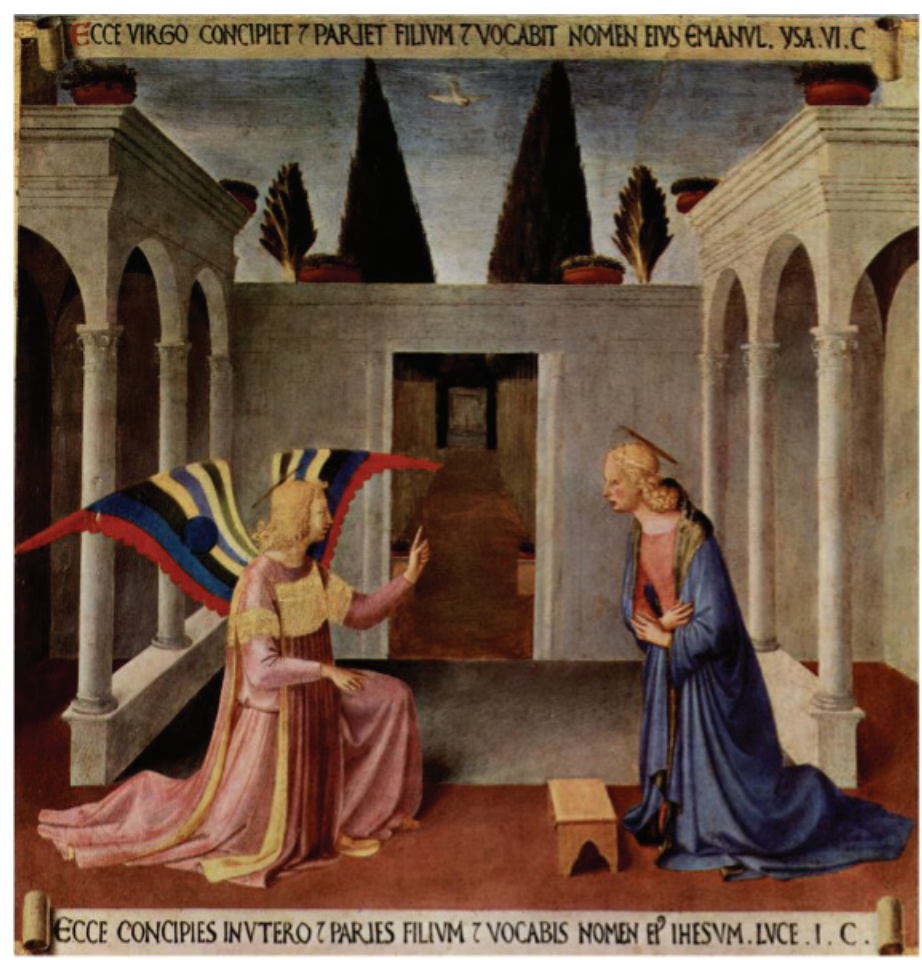

Foto: Wikimedia Commons. 
$\mathrm{Na}$ ordem de causalidade mais eficaz entre os franciscanos, preponderava uma forma mística de louvor arredia à intelecção detalhada da presença divina. Enquanto os dominicanos enfocavam a diferença segundo graus de participação por vezes meticulosamente caracterizados, franciscanos como Pierre Jean Olivi podem ter preferido identificar, em nome da salvaguarda da responsabilidade individual pelos pecados, a descontinuidade entre Deus e os homens. Recusando o que vituperava como "averroísmo", Olivi supunha a presença divina em negativo, isto é, pelos parâmetros inatingíveis de sua perfeição. Estando em todos os seres como substância, não assume responsabilidade por eles no plano dos atos e das instituiçôes (PIRON, 2019, p. 844-846).

Com isso, desaparece a prioridade ontológica para que prevaleça uma relação de simultaneidade entre as causas: considera-se que os agentes empíricos aperfeiçoam os atos do criador agindo livremente, embora dependam de seu concurso. Passa-se das causas per influentiam, influência do intelecto divino sobre a ação, a uma influentia generalis Dei, influência do intelecto divino com os agentes, nos termos de Boaventura (SCHMUTZ, 2001, p. 227-230); o movimento sinaliza que as razóes divinas não são aparentes nas coisas, identificando-se apenas os influxos de sua misteriosa influência. Os franciscanos náo anulam a organização analógica dos seres, mas localizam as açôes humanas em uma ordem que lhes determina maior responsabilidade por seus atos; não concebem uma natureza despida da ingerência divina, mas uma simplicidade natural que participa genericamente de sua substância, lumen gloriae vista apenas de modo indireto, por espelhos e enigmas. ${ }^{19}$

Por esse viés, a experiência de observar a Anunciação poderia repercutir a ordem divina nos limites do nomos e da physis (SCHMUTZ, 2001, p. 233), alegorizando a restriçâo do que pode ser de fato visto e compreendido pelo engenho humano. Esta aparece na Anunciação de Cortona, também atribuída a Fra Angelico (Figura 10). Maria e Gabriel empreendem o colóquio, visualmente disponível nas letras douradas inseridas entre eles. As palavras do anjo são legíveis - Spiritus Sanctus superveniet in te, et virtus Altissimi obumbrabit tibi (LUCAS, 1:35) -, ao passo que a resposta de Maria, Ecce ancilla Domini, fiat mibi secundum verbum tuum (LUCAS, 1:38), aparece invertida, técnica empregada para indicar que refletem a perspectiva de Deus, que as lê dos céus. Não descrevem o evento, mas o compóem, sendo expressão visual da encarnação do logos, em sua exuberante, embora inacessível, presença (HODNE, 2011, p. 261).

\footnotetext{
19 "A tradição franciscana aqui descrita transformou totalmente o sentido da noção: nela, a influência é despojada de qualquer dimensão formal, o que significa que o papel da causa primeira não é o de um simples agente ativo doador de ser. A questáo deixa de ser a de um influxus da causa primeira na segunda, mas simplesmente de uma influentia generalis da primeira com a segunda, dissociada de qualquer influência especial" [No original: La tradition franciscaine ici décrite a totalement transformé le sens de la notion : l'influence y est dépouillée de toute dimension formelle, ce qui signifie que le rôle de la cause première n'est pas celui d'un agent actif donateur d'être. Il n'est plus question d'un influxus de la cause première dans la seconde, mais simplement d'une influentia generalis de la première avec la seconde, découplée de toute influence spéciale"]. Tradução nossa. (SCHMUTZ, 2001, p. 237).
} 
Figura 10: Fra Angelico. Anunciação de Cortona, c. 1434. Têmpera sobre painel, 175 x 180 cm., Museo Diocesano.

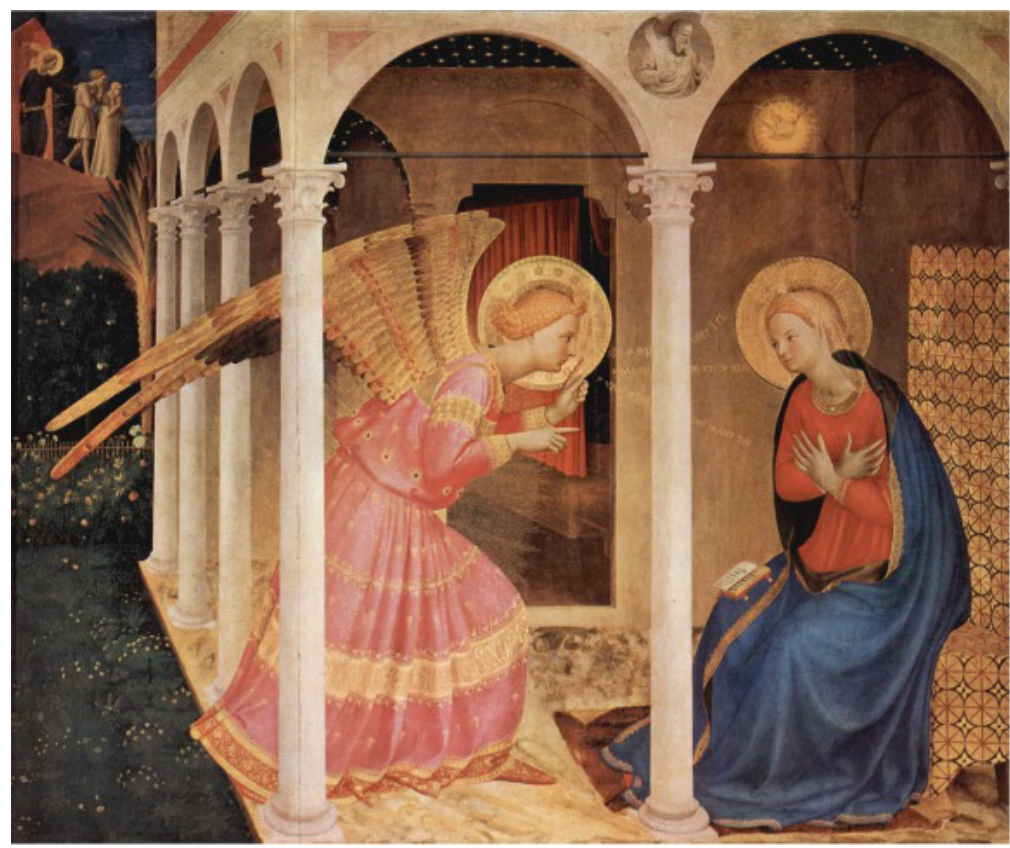

Foto: Wikimedia Commons.

Os observadores da Anunciaçâo de Cossa deviam perceber no retábulo um cenário realista complicado (CUSA, 2010, p. 185-187) pela incursão do sagrado. Nas antípodas do sucesso das técnicas bizantinas, que se valiam do segundo plano para explorar o estranhamento de uma dimensão alheia à humanidade, a partir do século XIV o projeto de uma cenografia concebida em função da realidade terrena ganhou força (MUZJ, 1996, p. 220-221). Em que medida ela esteve preenchida pelas metafísicas analogistas na perspectiva dos comitentes? A solenidade do evento, situada em um eterno presente, contrastaria com o tempo da vida, que avança em aparente indiferença - para Patricia Simons, as personagens não se atentam ao que sucede com Maria (SIMONS, 2015, p. 316). Estariam em erro ou simplesmente em outro tempo? O efeito da perspectiva poderia sugerir uma dilatação temporal, remetendo a uma experiência mística oculta, inapreensível aos seres que perambulam por Bolonha; mas se assim for, para quem a criança gesticula em saudação (Figura 11)? Se anularmos por um instante a ilusão da perspectiva, nada rigorosa em Cossa (ARASSE, 2019, p. 42), é a Maria que ela se destina. Do contrário, veríamos a criança gesticular na direção de algo que não vemos, na rua de trás, por onde passa o cão, e seríamos levados a imaginar que ali, fora do alcance da vista, transcorre a festa sagrada da Anunciação... Olhos que filtrassem as propriedades figurativas dessa forma detectariam uma influência geral, que se expressa metaforicamente no encontro entre a imagem e as formas de culto então predominantes na cidade. 
Figura 11. Francesco del Cossa. Anunciação (detalhe).

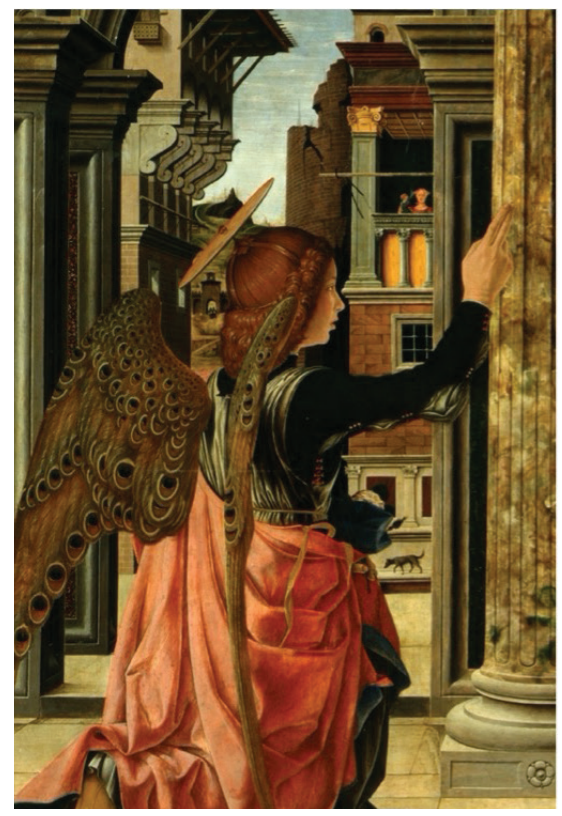

Questôes semelhantes se colocam no grupo principal. Comovido pela missa que guiava seu olhar ao retábulo, um dos devotos da Osservanza ${ }^{20}$ talvez pudesse constatar, estupefato, a ignorância dos homens; como não reconhecem, nas asas de Gabriel, as penas de pavão que, se substituindo a cada outono, aludem à reatualização da vida (DOMÍNQUEZ, 2000, p. $54)^{21}$ ? Como não veem o nexo flagrante entre o Verbo encarnado e a Eucaristia? Como não testemunham, prudentes, a roda do tempo desenhada no caracol, onde escorrem, lenta e inexoravelmente, as sucessóes da história, pelos séculos dos séculos, até a salvação? Como não percebem neste tempo comprimido entre as paredes impossíveis da casa de Maria a alegria de um verdadeiro milagre prestes a escapar dos limites da tela? Sabedores, como ele, da ignorância humana, se interrogariam sobre isso enquanto experimentam a redenção depositada na hóstia, admitindo, com compenetrada humildade e merecida devoção, esta epifania: somente Deus vê tudo; vê porque está nos céus, de onde parte o raio de luz trazido pela colomba do Espírito Santo; vê porque está na Terra, figurado nos olhos que se alastram sobre as asas de Gabriel (Figuras 12 e 13) 22 , de onde sopesa, onisciente, a extensão dos pecados que se aninham nos corações humanos. A especulação ilumina a parcialidade da célebre solução ofere-

\footnotetext{
${ }^{20}$ Concebido aqui, evidentemente, como tipo que denota um uso possível dos modos de identificação, e não como resultado de conjectura empírica atrelada a um contexto decerto perdido.

${ }^{21}$ Seu uso em uma Anunciação de Lippi (Figuras 12 e 13) comprova ter sido marca técnica do gênero disponível a Cossa, viabilizando nossa leitura, anteriormente marcada por Feuillet (2008, p. 3-4).

${ }^{22}$ Estaríamos cedendo demasiadamente às tentaçóes iconográficas se tomássemos o marrom das asas do anjo como ícone do hábito franciscano que o devoto veste em meio a essas elucubraçóes, signo de que se encontra no bom caminho para sondar, com a benevolência da graça divina, a consagração dos mistérios (FEUILLET, 2008, p. 3-4)? Não iremos tâo longe.
} 
cida por Daniel Arasse ao interpretar o retábulo; quando sugere que "nada se vê naquilo que se olha”, isto é, que, a exemplo do caracol, os comitentes eram cegos à plenitude do invisível "que escapa a toda medida" (ARASSE, 2019, p. 44), poderia ter enfatizado na mesma medida que, para eles, os olhos do criador não estavam obstruídos, e se situavam mais perto do que se imagina.

Figura 12: Francesco del Cossa. Anunciação (detalhe).

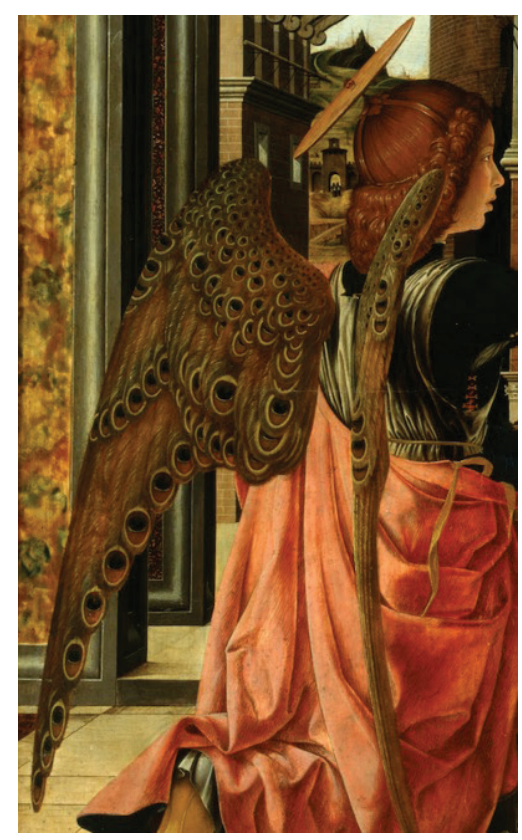

Figura 13: Filippo Lippi. Anunciação (detalhe), c. 1449-1459. Têmpera sobre madeira, $68 \times 151,5 \mathrm{~cm}$,

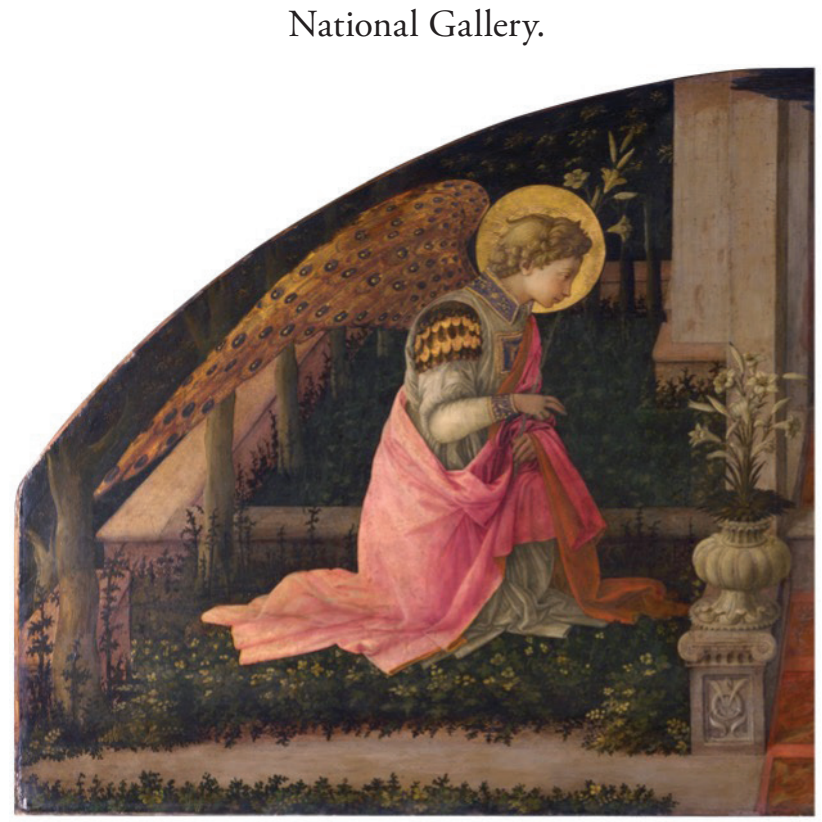

Foto: Wikimedia Commons.

\section{Mecanismos da hibridação}

Como vimos, os pintores do primeiro naturalismo elaboraram técnicas que visavam à adequação realista. A partir desse momento, com a pintura se fabricou, cada vez mais claramente, uma janela ${ }^{23}$ para indivíduos empíricos ocupados com açóes verossímeis em locais verossímeis. Mas a atitude técnica não podia prescindir do reconhecimento dos fenômenos espirituais, nem do caráter substancialista de discursos que enunciavam o mundo antes de re-

23 "A aplicação da perspectiva, lembramos, implica que a superfície pintada é entendida como uma 'janela' através da qual observamos uma seção do espaço. Se tomado a sério, isso significa, nada mais, nada menos que não deve haver qualquer contradição evidente entre o que vemos em uma pintura e o que podemos ver na realidade" [No original: "The application of perspective, we remember, implies that the painting surface is understood as a 'window' through which we look out into a section of space. If taken seriously, this means no more nor less than that pictorial space is subject to the rules that govern empirical space, that there must be no obvious contradiction between what we do see in a picture and what we might see in reality"] (PANOFSKY, 1966, p. 140-141). Tradução nossa. 
presentá-lo. A resposta a essas diretrizes foi um princípio ordenador qualificado por Panofsky de "simbolismo disfarçado": "Quanto mais os pintores se compraziam em descobrir e reproduzir o mundo visível, mais intensamente sentiam a necessidade de saturar todos os seus elementos de sentido" (PANOFSKY, 1966, p. 142). ${ }^{24}$ O dualismo extraído dessa descrição nem sempre foi assimilado sem levar em conta o princípio, ainda não de todo superado, de uma naturalização objetivada. As condiçôes ontológicas de observação do retábulo de Cossa o problematizam, mostrando a contiguidade que os emergentes procedimentos técnicos de codificação do real mantinham com um sistema de inferências expresso por um vocabulário metafisicamente orientado. ${ }^{25}$

Este não era, porém, absoluto, nem os símbolos do retábulo se reduziam às possíveis explicaçôes que oferecemos. Vista por outros olhos, a simbiose entre Bolonha e Nazaré poderia valorizar, por exemplo, uma marca de gosto e de louvor citadino, mitigando os traços analogistas para privilegiar propriedades naturalistas - a demonstração pictórica de um espaço ordenado por um ponto de vista imperial e a disposição dos seres de acordo com o posicionamento verossímil de seus corpos, entre outras habilidades relativas à proporcionalidade e solidez figurativas (DESCOLA, 2011, p. 696). Mas é mais provável que esse campo de possibilidades estivesse estruturado, ao menos entre os frequentadores da Osservanza, na interdependência das opçóes geométricas da pintura quatrocentista e do aparato ontológico predominante. ${ }^{26}$

O realismo híbrido que as pinturas expóem auxilia-nos a reintroduzir o estranhamento necessário à observação dos modos de relacionamento da interioridade humana com a materialidade que a circunda; se os estudos historiográficos, sociológicos e a arqueologia do meio ambiente têm indicado um processo de antropização acentuado entre os séculos XIII e $\mathrm{XV}$, com o controle dos espaços florestais, o domínio sistematizado da agricultura e a polderização de terras baixas, este não pode ser reduzido a um estágio embrionário da conquista de uma natureza primitiva (ANHEIM, 2018, p. 53), pois as inferências subjacentes a essas açóes não prescindiam da espiritualização que, no plano ontológico, desconhecia os limites

\footnotetext{
${ }^{24}$ No original: "The more the painters rejoiced in the discovery and reproduction of the visible world, the more intensely did they feel the need to saturate all of its elements with meaning" (PANOFSKY, 1966, p. 140-141). Tradução nossa.

${ }^{25} \mathrm{O}$ que nos permite, de resto, endossar a análise de Patricia Simons: "a caracterização corriqueira, no discurso moderno, da pintura do Renascimento como uma 'janela' transparente para a realidade não tem qualquer sentido aqui. Arquitetura e perspectiva simultaneamente enredam o observador na decisiva doutrina cristá da salvação ao mesmo tempo em que deixam claro que Deus fez o impossível". [No original: "the trite characterization in modern discourse of the Renaissance painting as a transparent 'window' onto reality has no logic here. Architecture and perspective simultaneously enwrap the viewer into the central Christian doctrine of salvation while making it clear that God enacted the impossible"] (SIMONS, 2015, p. 319). Tradução nossa.

${ }^{26}$ O equívoco, neste caso, seria construído sobretudo a partir de uma leitura anacrônica do Della pittura: "ficando-se em Da pintura, a perspectiva não é exposta nela senão como parte de parte da pintura, da 'composição', retoricamente ordenada, e não como assunto isolável, que se tenha por principal” (KOSSOVITCH, 1994, p. 67).
} 
hoje vigentes a opor o humano e o natural, qualificando os usos do espaço físico na ordem de imperativos "culturais" (BAXANDALL, 1991, p. 177). O mesmo se aplica à pintura, que então desconhecia a generalização de uma forma simbólica filosoficamente racionalizada. ${ }^{27}$ No caso de Cossa, os traços realistas não estavam propriamente saturados de sentidos simbólicos; antes, o realismo da representação é que havia sido construído em função de uma rede de similitudes que assinalava conveniências entre a linguagem pictórica e as propriedades metafísicas do mundo como um todo na reiteração cotidiana de práticas guiadas pelos modos de identificação disponíveis. ${ }^{28}$

Reconhecer que uma figuração naturalista sobreposta ao modo de identificação analogista não antecipa, senão em conceitos anacronicamente aplicados a seus resíduos, o que chamamos de "modernidade", pode não somente aperfeiçoar a análise da fabricação e consumo dos objetos artísticos, mas estabelecer em bases mais sólidas a distância que nos separa das modalidades de sua contemplação. Ao dar primazia às propriedades dos signos sobre os conteúdos das técnicas e ao denominar analogista um sistema de inferências que conciliou, segundo graus de semelhança, a alteridade e a unidade, o material e o imaterial, os indivíduos e o ambiente, defendemos uma etiologia que permita iluminar estratégias históricas de autorização dos discursos, entre eles os visuais, recusando perspectivas analíticas que escamotearam as aparentes antinomias da representação quatrocentista para não ter de lidar com o seu caráter ontologicamente relativo.

\section{Referências}

\section{Obras antigas}

ALBERTI, Leon Battista. La pittura di Leon Battista Alberti Tradotta per M. Lodovico Domenichi. In Vinegia Appresso Gabriel Giolito de Ferrari, 1547.

BIBLIA VULGARE ISTORIATA. Ne lalma citta de Venetia: per Giovanne Ragazo a instantia di Luchantonio di Giunta, a di XV de octubrio 1490.

BÍBLIA. Novo Testamento. Trad. Frederico Lourenço. São Paulo: Companhia das Letras, 2017.

\footnotetext{
27 "Francesco del Cossa não tinha lido Panofsky. Ele não sabia que a perspectiva ia se tornar, como a definiu retrospectivamente o intelectual alemão, a 'forma simbólica' de uma visão de mundo que seria racionalizada por Descartes e formalizada por Kant” (ARASSE, 2019, p. 42).

${ }_{28}^{28}$ Ainda que calcada em pressupostos distintos, esta leitura vai ao encontro da análise de Simons (2015), para quem os devotos distinguiam no retábulo a emergência de um cotidiano subitamente sobressaltado pela intervenção divina: "a exemplo de Maria, movemo-nos, como um caracol, de um momento ordinário da vida para a referência perante a irrupção divina de um momento histórico” (p. 316).
} 
COSSA, Francesco. Lettera a Borso d'Este. In: VENTURI, Adolfo. Gli affreschi del Palazzo di Schifanoia in Ferrara: Secondo recenti pubblicazioni e nuove ricerche. Atti e memorie della deputazione di storia patria. Bologna: Deputazione di Storia Patria, 1885.

CUSA, Nicolau de. A visão de Deus. Trad. João Maria André. Lisboa: Calouste Gulbenkian, 2010.

LEONI, Tommaso. Manoscritto dele Sacre Rappresentazioni ad uso della Compagnia di S. Girolamo di Bologna. Ms. Vitt.Em.483, 1486.

SALIMBENI, Angelo Michele; ALDROVANDI, Sebastiano. Philomathia. A cura di Nicolò Groja. Venezia: Edizioni Ca’Foscari, 2017.

\section{Bibliografia citada}

ANHEIM, Etienne. Les métamorphoses de la nature. In: DESCOLA, Philippe (org.). Les natures en question. Paris: Odile Jacob, 2018.

ARASSE, Daniel. Nada se vê: seis ensaios sobre a pintura. Trad. Camila Boldrini \& Daniel Lühmann. São Paulo: Editora 34, 2019.

AUERBACH, Eric. Figura. São Paulo: Ática, 1997.

BAXANDALL, Michael. Giotto e os oradores: as observaçóes dos humanistas italianos sobre pintura e a descoberta da composição pictórica (1350-1450). Trad. Fábio Larsson. São Paulo: EdUSP, 2018.

BAXANDALL, Michael. $O$ olhar renascente: pintura e experiência social na Itália da Renascença. Trad. Maria Cecília P. R. Almeida. Rio de Janeiro: Paz \& Terra, 1991.

BAXANDALL, Michael. Padróes de intenção: a explicaçáo histórica dos quadros. Trad. Vera Maria Pereira. São Paulo: Companhia das Letras, 2006.

BAXANDALL, Michael. Words for pictures: seven papers on Renaissance art and criticism. New Haven: Yale University Press, 2003.

BLACK, Robert. Uses and abuses of iconology. The Oxford Art Journal, n. 9, p. 2, 1986.

BORELLA, Jean. Penser l'analogisme. Paris: L'Harmattan, 2000.

BURCKHARDT, Jacob. A cultura do Renascimento na Itália. Trad. Sergio Tellaroli. São Paulo: Companhia das Letras, 2003.

DASTON, Lorraine. Against nature. London: MIT Press, 2019.

DESCOLA, Philippe. De la Nature universelle aux natures singulières: quelles leçons pour l'analyse des cultures? In: DESCOLA, Philippe (org.). Les natures en question. Paris: Odile Jacob, 2018.

DESCOLA, Philippe. Modes of being, forms of predication. HAU - Journal of Ethnographic Theory, v. 4, n. 1, 2014. 
DESCOLA, Philippe. Ontologie des images (suite et fin). 2011. Disponível em: https:// www.college-de-france.fr/site/philippe-descola/. Acesso em: 19 fev. 2020.

DESCOLA, Philippe. Ontologie des images (suite). 2010. Disponível em: https://www. college-de-france.fr/site/philippe-descola/. Acesso em: 20 fev. 2020.

DESCOLA, Philippe. Ontologie des images. 2009. Disponível em : https://www.college-defrance.fr/site/philippe-descola/. Acesso em : 20 fev. 2020.

DESCOLA, Philippe. Par-delà nature et culture. Paris: Gallimard, 2005.

DOMÍNQUEZ, Martí. Naturaleza y símbolo. La interpretación de la naturaleza en la pintura del Renacimiento. Pasajes, n. 4, 2000.

FEUILLET, Michel. Le bestiaire de l'Annonciation: l'hirondelle, l'escargot, l'écureuil et le chat. Italies, Revue d'Études Italiennes, n. 12, 2008.

FLOR, Pedro. A arte do retrato em Portugal nos séculos XV e XVI. Lisboa: Assírio \& Alvim, 2010.

GILSON, Etienne. A filosofia na Idade Média. Trad. Eduardo Brandão. São Paulo: Martins Fontes, 2001.

FOUCAULT, Michel. As palavras e as coisas: uma arqueologia das ciências humanas. Trad. Salma Tannus Muchail. São Paulo: Martins Fontes, 2016.

GHELARDI, Maurizio. La violence de l'interprète. In: WARNKE, Martin et al. (orgs.). Relire Panofsky. Paris: Musée du Louvre Éditions, 2008.

GILSON, Etienne. O espírito da filosofia medieval. Trad. Eduardo Brandão. São Paulo: Martins Fontes, 2006.

GOMBRICH, Ernst. Arte e ilusão: um estudo da psicologia da representação pictórica. Trad. Raul de Sá Barbosa. São Paulo: Martins Fontes, 2007.

GROJA, Nicolò. La Philomathia di Angelo Michele Salimbeni e Sebastiano Aldrovandi: cenni di analisi. Venezia: Edizioni Ca’Foscari, 2017.

HARCK, Fritz. Gli affreschi del Palazzo di Schifanoia in Ferrara. Trad. A. Venturi. Antonio Taddei e Figli, 1886.

HODNE, Lasse. Reading and Viewing Words in Fra Angelico's Typological Paintings. Acta ad archaeologiam et artium historiam pertinentia, v. 24, n. 10, 2011.

KANTOROWICZ, Ernst. La souveraineté de l'artiste: note sur quelques maximes juridiques et les théories de l'art à la Renaissance. In: KANTOROWICZ, Ernst. Mourir pour la patrie. Paris: Fayard, 2004.

KOSSOVITCH, Leon. Contra a ideia de Renascimento. In: NOVAES, Adauto (org.). Artepensamento. São Paulo: Companhia das Letras, 1994.

LAW, John E. Cosmè Tura e Francesco del Cossa. L'Arte a Ferrara nell'Età di Borso d'Este. 
Renaissance Studies, v. 23, n. 5, 2009.

LIBERA, Alain de. Arqueologia do sujeito: nascimento do sujeito. Trad. Fátima C. Murad. São Paulo: FAP-UNIFESP, 2013.

LIPPINCOTT, Kristen. Francesco del Cossa. Oxford Art Online. 2003. Disponível em: https:/www.oxfordartonline.com/groveart/view/10.1093/gao/9781884446054.001.0001/ oao-9781884446054-e-7000019720? rskey=KUrkVO\&result=1. Acesso em: 1 mar. 2020.

LLOYD, Geoffrey. Cognitive variations: reflections on the unity and diversity of the human mind. Oxford: Oxford University Press, 2007.

MANCA, Joseph. Francesco del Cossa's call for justice. Notes in the History of Art, v. 12, n. 3, 1993.

MANCA, Joseph. Style, Clarity, and Artistic Production in a Courtly Center: Some Myths about Ferrarese Painting of the Quattrocento. Artibus et Historiae, v. 22, n. 43, 2001.

MOCHIRI, Pouneh. Le modèle analogique du paragone à la Renaissance. In: MICHEL, Christian (org.). Le démon de l'analogie: analogie, pensée et invention d'Aristote au XXe siècle. Paris: Classiques Garnier, 2016.

MUZJ, Maria Giovanna. L'iconografia dell'Annunciazione. Theotokos, IV, 1996/2.

NYGREN, Barnaby. Immersed in things of the body: humor and meaning in an "Annunciation" by Filippo Lippi. Studies in Iconography, v. 25, 2004.

PANOFSKY, Erwin. Early Netherlandish paiting: its origins and character. Cambridge: Harvard University Press, 1966.

PÉCORA, Alcir. A história como colheita rústica de excelências. In: SCHWARTZ, Stuart B; PÉCORA, Alcir (orgs.) As excelências do governador. São Paulo: Companhia das Letras, 2002. PHILLIPS-COURT. Framing the Miracle in Feo Belcaris "Rapresentazione quando la Nostra Donna Vergine Maria fu annunziata dall'Angelo Gabriello". Annali d'Italianistica, v. 25, 2007.

SCHMUTZ, Jacob. La doctrine médiévale des causes et la théologie de la nature pure. Revue Thomiste, n. 101, 2001.

SIMONS, Patricia. Salience and the snail: liminarity and incarnation. In: GOW, Andrew Colin (org.). Religion, the supernatural and visual culture in Early Modern Europe. Leiden: Brill, 2015.

SWAN, Claudia. Ad vivum, naer het leven, from the life: defining a mode of representation. Word \& Image: a Journal of Verbal/Visual Enquiry, n. 11, p. 4, 1995.

TERPSTRA, Nicholas. Lay confraternities and civic religion in Renaissance Bologna. Cambridge: Cambridge University Press, 1995. 